\title{
Waste water treatment and pollution control in the Liao River Basin
}

\author{
Yonghui Song ${ }^{1} \cdot$ Ruixia Liu $^{1} \cdot$ Yuanyuan Sun $^{1} \cdot$ Kun Lei $^{1} \cdot$ Olaf Kolditz $^{2,3,4}$
}

Published online: 8 April 2015

(C) Springer-Verlag Berlin Heidelberg 2015

Rapid economic development and population growth in China go hand-in-hand with increasing urbanisation, involving growing mega-cities, industrialization, and intensified agriculture. As a result, natural resources are increasingly stressed and productive management strategies towards sustainable planning are urgently needed. Pollution containing hazardous substances for environmental and human health, depletion of water resources as a result of overexploitation, soil degradation and air pollution in mega-cities (such as Beijing or Shanghai) are increasing at an alarming rate. Consequently, the protection of aquatic ecosystems and the security of drinking water provision are becoming an increasing challenge in water management. The Chinese government recognized the importance and complexity of the situation and has initiated a program entitled "Major Program of Science and Technology for Water Pollution and Governance" (2006-2020) (Major Water Program). While shortages resulting from regional resource depletion have led to plans for large-scale water transport from distant water-rich areas of China (Water Diversion Project), the water quality problems in other areas require efficient, flexible, and site-specific solutions and overall management concepts. China is internationally cooperating with many countries to tackle the severe

Olaf Kolditz

olaf.kolditz@ufz.de

1 Chinese Research Academy of Environmental Sciences (CRAES), Beijing, China

2 Helmholtz Centre for Environmental Research (UFZ), Leipzig, Germany

3 Technische Universität Dresden (TUDD), Dresden, Germany

4 Sino-German Research Centre for Environmental Information Science (RCEIS), Berlin, Germany environmental problems and learning from their experiences. In particular, China can benefit from the lessons learnt in Germany concerning the rehabilitation of water resources in areas heavily affected by chemical industry and mining after the reunification in 1989. German-Chinese cooperation in water sciences started over 25 years ago and is dealing now with increasing challenges in the 21st century (Chen et al. 2015). Under the umbrella of "International Partnerships for Sustainable Technologies and Services for Climate Protection and the Environment" (CLIENT) under the "Research for Sustainable Development" framework programme the Federal Ministry of Education and Research of Germany (BMBF) started a series of research projects supporting the Chinese Major Water Program in several regions, the lakes, Taihu, Chaohu and Dianchi, as well as the Liao River Basin (Fig. 1).

The Liao River Basin is located in northeast China with two river systems, one system is the Liao River formed by converging Xiliao River and Dongliao River, and the other system is the Daliao River formed by converging Hun River and Taizi River (Fig. 1). The province of Liaoning derived its name from the river. Shenyang is the provincial capital of Liaoning. Liaoning was one of the first provinces in China to industrialize and heavy industry led to severe environmental pollution including the water environment. Liaoning has the largest economy of Northeast China covering a wide range of industries, such as metallurgy, petroleum, chemical industries, pulp and paper making, pharmaceutical industry, printing and dyeing, machinery, electronics, metal refining, construction materials, ore and coal mining, etc. The Liaohe-Songhuajiang River Basin belongs to the priority areas of the Chinese Major Water Program. The Chinese central government launched a "Revitalizing Northeast China and Other Old Industrial Bases" campaign (2005, http://www.china.org.cn/e-news/ 
Fig. 1 The Liao River Basin with its tributaries (Source: Liaorivermap by KmusserOwn work using Digital Chart of the World and GTOPO data. Licensed under CC BY-SA 3.0 via Wikimedia Commonshttp://commons.wikimedia.org/ wiki/File:Liaorivermap.png\#/ media/File:Liaorivermap.png)

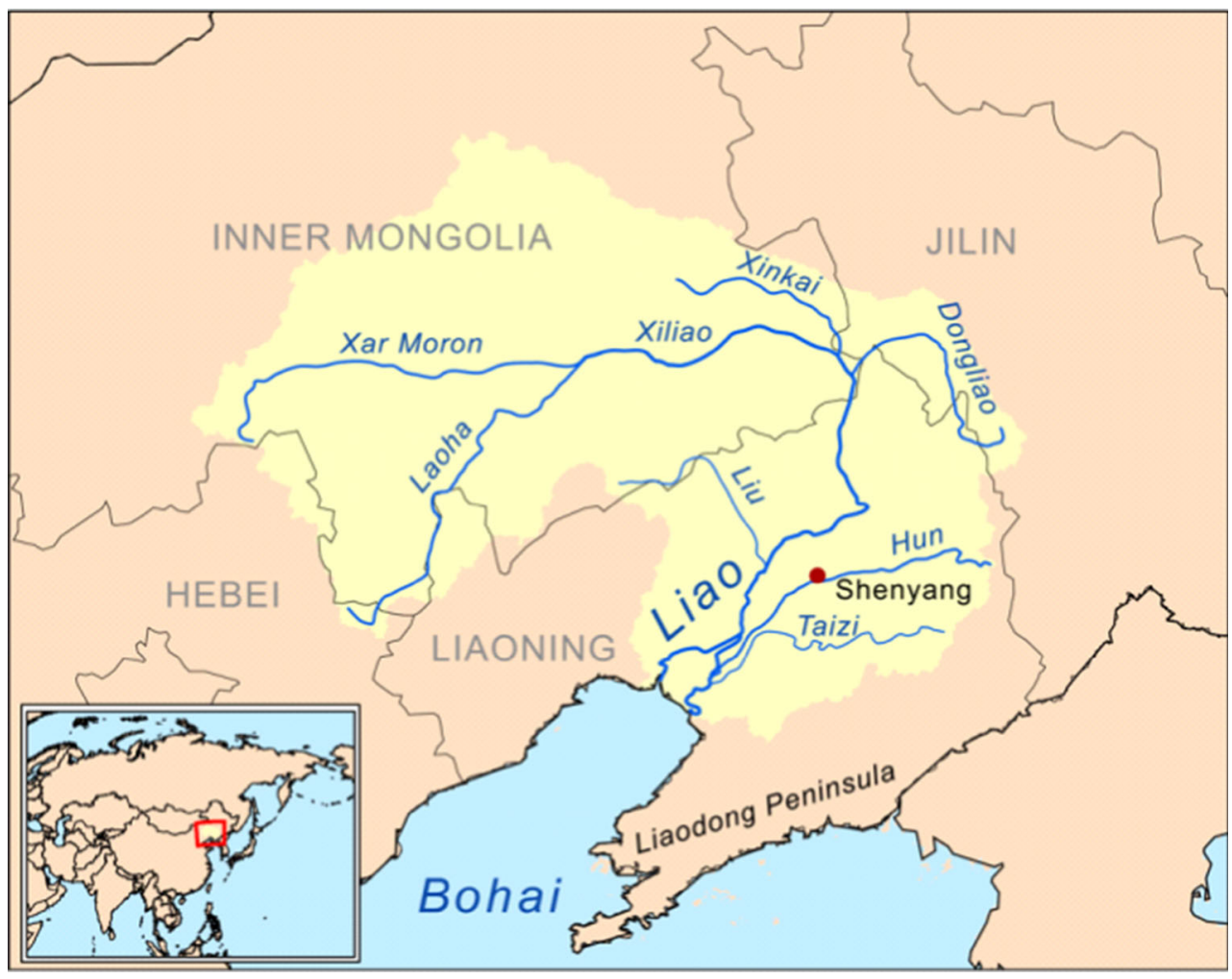

news050302.htm), and recently a "Shenyang Economic Zone" strategy (2011, http://baike.baidu.com/subview/ 7141967/7293502.htm). The social-economic development of Liao River Basin needs the supports of good water resource and environment. The Major Water Program took Liao River Basin as one of the most important demonstration basins, and set up a full project under the river theme in the first stage of the program (2008-2010), focusing on pollution source control technology development; and continued such a project in the second stage (2011-2015), focusing on pollution load reduction and water environment restoration. Besides, under the monitoring and early warning theme, the research on water environment management has been continuously carried out in Liao River Basin since the beginning of the program. The technology development strategy of the Major Water Program includes original innovation and integration innovation. The program always aims at not only the forefront of technology development, but also the needs of the environment quality improvement.

The major topics of the Liaohe Thematic Issue are dealing with waste water treatment technologies, pollution control in the river basin, emerging pollutants, and socioeconomic studies.

The efficiency of waste water treatment technologies, particularly membrane bioreactors (MBR), has been studied by several authors. Duan et al. (2015a) investigated the combination of moving bed biofilm reactor and conventional membrane bioreactor (MBR) and compared the performance of bioreactors and membrane fouling using lab reactors. In a second study, Duan et al. (2015b) elaborated on integrated fixed-film activated sludge membrane reactors and investigated the characteristics of microbial activities in different MBR systems. Tian et al. (2015a) improved the efficiency of an existing WWTP by using membrane bioreactors. They studied the deficiencies of alkalinities and carbon sources hindering nitrogen removal. Fenton oxidation was used for pretreatment of waste water to improve chemical oxygen demand (COD) removal efficiency by Wei et al. (2015). Wan et al. (2015) and Song et al. (2015a) used membrane technologies for copper removal from aqueous solutions and amantadine by liquid-liquid extractions, respectively. Some technologies allowed for recovery of chemical from wastewater (Liu et al. 2015a). Related previous works on MBR are dealing with emerging contaminants from landfill leachates and their sustainable management (Ramakrishnan et al. 2015) and the removal of di-/pentachlorophenol from aqueous media by electrochemical process (Huang et al. 2013).

Pharmaceutical wastewater is an important threat for contaminations. One of those emerging pollutants is berberine, which is a quaternary ammonium salt from the protoberberine group of isoquinoline alkaloids. Berberine is chemically produced mainly in the Liaohe basin as a 
broad-spectrum antibiotica (Tu et al. 2015). Qin et al. (2015) investigated the degradation of antibiotic berberine hydrochloride. They evaluated the removal efficiency of berberine hydrochlorides and conducted cost analysis. Xiao et al. (2015) applied photo-electrochemical processes in the presence of chlorides for degradation of berberine. Shan et al. (2015) investigated the adsorption kinetics and thermodynamics of berberine. Recent related works on pharmaceutical waste water are dealing with risks from sedimentary trace metals in response to industrialization from the tributaries (Tang et al. 2015). Cui et al. (2015) investigated pharmaceutical waste water treatment, particularly berberine removal, by Fenton oxidation at pilot scale. Different and combined technologies such as Fenton and ultrasonic processes have been compared by Zeng et al. (2015). Burke et al. (2014) studied redox-dependent removal of organic trace pollutants by using tank aeration experiments. A bibliometric analysis on pharmaceutical waste water treatment in the last decade has been provided by Qian et al. (2015). Schirmer et al. (2011) investigated aspects of emerging pollutants in Germany, Halle/Saale and Leipzig by exploring contaminant mass balances.

Liu et al. (2015a) evaluated the properties of proteins in waste activated sludge (WAS) and the effect of sludge proteins on volatile fatty acids. This seems an attractive practice for efficient waste treatment. Different aspects sludge treatment, such as reactivation and succession of microbial communities and fermentation, were investigated by Peng et al. (2015a) and Liu et al. (2015a), respectively. Nitrogen removal from waste water is an important issue for water quality improvement in China (Gao et al. 2015a) and other countries (Al Dwairi et al. 2014; Cicchella et al. 2014; Pascual Aguilar et al. 2014). Li et al. (2015a) developed a novel system for autotrophic sulfur denitrification to enhance nitrogen removal from municipal waste water. Understanding of autotrophic denitrification processes is essential site implementations e.g., in constructed wetlands (Huang et al. 2013; Lei et al. 2013). Tian et al. (2015a) investigated several key factors influencing the nitrogen removal efficiency by bio-filters and different ambient temperatures. Recent related international works on nitrogen removal are from Poland (Dragon 2013) dealing with groundwater nitrate pollution in the recharge zone of a regional Quaternary flow systems which is an important issue in many areas of China as well (Sun et al. 2012). The correlation between nitrite accumulation and the concentration nitritation reactors has been studied in Korea (Im and Gil 2013, Im et al. 2014).

Several works are dealing with studies in the Liao River Basin and the tributaries (Ma et al. 2015). Gao et al. (2015a) investigated water quality variations at different time and spaces in the Pu River using multivariate statistical method to analyze water quality indicators measured at different sites in the period from 2012 to 2013. Several studies are dedicated to the study of dissolved organic matter (DOM) in the river basin (Yu et al. 2015). Zhi et al. (2015a, b) found that microbial communities play a key role in wetland water purification and nitrogen cycling. In the Jiulong River, Luo et al. (2014) studied the dynamics of ammonia-oxidizing archaea and bacteria in relation to nitrification along simulated dissolved oxygen gradient in sediment-water interface of the river estuarine wetland. Peng et al. (2015a) stated that potential water pollution derived from melting snow is a growing concern to watershed management in northern climates such as in Northeast China. For most small watersheds in the Hun River Basin, substantial portions of the annual load of pollutants such as organic matter, ammonia, phosphorus and metals come from snowmelt and early spring runoff. $\mathrm{Li}$ et al. (2015a) studied the occurrence and distribution of phthalic acid esters and phenols in the Hun River watersheds. Complementary, Guo and He (2013) investigated spatial variations and ecological risk assessment of heavy metals in surface sediments on the upper reaches of Hun River. Han et al. (2015) studied DOM aspects and pollution from waste water discharge into the urban Xihe River, Shenyang. Quiers et al. (2014) conducted similar studies concerning the characterization of rapid infiltration flows and vulnerability using a decomposed fluorescence signal of dissolved organic matter in karst aquifers. Liu et al. (2015a) provided an overview of persistent organic pollutants (POPs) and heavy metals in the Liao River Basin.

In addition to the works in engineering and natural sciences, socio-economic studies have been completed as well. Yang et al. (2015) developed a concept of water environmental carrying capacity (WECC) which can be used to describe water environmental system's capacity and support socio-economic development, and examine the trade-off between the driver/pressure (socio-economic) and the support (environmental) components of the societalenvironmental interactive system. The complexity of solving water resources management problems requires integrated approaches. Integrated water resources management (IWRM) is an approved concept to tackle the management of river basins and watersheds. Hydrosystem analysis tools including workflow concepts are important instruments for IWRM approaches (Kalbacher et al. 2012; Kolditz et al. 2012a) including reactive transport processes (Xie et al. 2006). Examples for IWRM approaches have been recently developed and applied e.g., in the IWASInternational Water Alliance Saxony (Kalbus et al. 2012; Seegert et al. 2014a, b) and WESS-Water Earth System Science (Grathwohl et al. 2013) initiatives. Novel technologies for hydrosystem analysis such as workflows (Kolditz et al. 2012b) including hierarchical monitoring concepts (Sauer and Dietrich 2014) and visualization (Rink 
et al. 2012; Bilke et al. 2014) are emerging topics in order to cope with the Big Data paradigm in Environmental Earth Sciences.

The Liaohe Thematic Issue is an achievement of the collaboration of the Chinese and German researchers, which opens a window to the world from the huge building of the Major Water Program of China, and it also symbolizes a good start of the Sino-German cooperation for the joint research and communication on water resource and environment.

Acknowledgments The Chinese side gratefully appreciates the funding by various national and international organizations which is specifically acknowledged in the individual publications, especially the projects of Major Program of Science and Technology for Water Pollution and Governance for Liao River Basin. The German side gratefully acknowledges the support by the Helmholtz Association (funding the German-Chinese Research Centre for Environmental Information Sciences-RCEIS), the Federal Ministry of Education and Research (BMBF) of Germany (funding the CLIENT China Projects, e.g., Urban Catchments, SIGN, SinoWater), the European Union (funding the SUSTAIN H2O project) and the Sino-German Centre for Science Promotion (funding the Poyang Lake workshop).

\section{References}

Al Dwairi RA, Ibrahim KM, Khoury HN (2014) Potential use of faujasite-phillipsite and phillipsite-chabazite tuff in purification of treated effluent from domestic wastewater treatment plants. Environ Earth Sci 71(12):5071-5078

Bilke L, Fischer T, Helbig C, Krawczyk C, Nagel T, Naumov D, Paulick S, Rink K, Sachse A, Schelenz S, Wal-ther M, Watanabe N, Zehner B, Ziesch J, Kolditz O (2014) VISLAB-laboratory for scientific visualization. Environ Earth Sci 72:3881-3899. doi:10.1007/s12665-014-3785-5

Burke V, Richter D, Hass U et al (2014) Redox-dependent removal of 27 organic trace pollutants: compilation of results from tank aeration experiments. Environ Earth Sci 71(8):3685-3695

Chen C, Boernick H, Cai Q, Dai X, Jaehnig SC, Kong Y, Krebs P, Kuenzer C, Kunstmann H, Liu Y, Nixdorf E, Pang Z, Rode M, Schueth C, Song Y, Yue TX, Zhou K, Zhang J, Kolditz O (2015) Challenges and opportunities of German-Chinese cooperation in water science and technology. Environ Earth Sci. doi:10.1007/ s12665-015-4149-5

Cicchella D, Giaccio L, Lima A et al (2014) Assessment of the topsoil heavy metals pollution in the Sarno River basin, south Italy. Environ Earth Sci 71(12):5129-5143

Cui X, Zeng P, Qiu G, Liu Y, Xie X, Song Y, Han L (2015) Pilot scale treatment of pharmaceutical berberine wastewater by Fenton oxidation. Environ Earth Sci. doi:10.1007/s12665-0154342-6

Dragon K (2013) Groundwater nitrate pollution in the recharge zone of a regional Quaternary flow system (Wielkopolska region, Poland). Environ Earth Sci 68(7):2099-2109

Duan L, Li S, Han L, Song Y, Zhou B, Zhang J (2015a) Comparison between moving bed-membrane bioreactor and conventional membrane bioreactor systems. Part I: membrane fouling. Environ Earth Sci. doi:10.1007/s12665-015-4159-3

Duan L, Tian Y, Liu X, Song Y, Yang L, Zhang J (2015b) Comparison between moving bed-membrane bioreactor and conventional membrane bioreactor systems. Part II: bacterial community. Environ Earth Sci. doi:10.1007/s12665-015-4245-6

Gao H, Lv C, Song Y, Zhang Y, Zheng L, Wen Y, Peng J, Yu H (2015a) Chemometrics data of water quality and environmental heterogeneity analysis in Pu River, China. Environ Earth Sci. doi:10.1007/s12665-015-4233-X

Gao H, Lv C, Song Y, Zhang Y, Zheng L, Wen Y, Peng J, Yu H (2015b) Chemometrics data of water quality and environmental heterogeneity analysis in Pu River. Environ Earth Sci, China. doi:10.1007/s12665-015-4233-X

Gao H, Song Y, Lv C, Chen X, Yu H, Peng J, Wang M (2015c) Possible allelopathic effect of Hydrilla verticillata on phytoplankton in nutrient rich water. Environ Earth Sci. doi:10.1007/ s12665-015-4316-8

Grathwohl P, Rügner H, Wöhling T, Osenbrück K, Schwientek M, Gayler S, Wollschläger U, Selle B, Pause M, Delfs J-O, Grzeschik M, Weller U, Ivanov M, Cirpka OA, Maier U, Kuch B, Nowak W, Wulfmeyer V, Warrach-Sagi K, Streck T, Attinger S, Bilke L, Dietrich P, Fleckenstein JH, Kalbacher T, Kolditz O, Rink K, Samaniego L, Vogel H-J, Werban U, Teutsch G (2013) Catchments as reactors-a comprehensive approach for water fluxes and solute turn-over. Environ Earth Sci 69(2):317-334. doi:10.1007/s12665-013-2281-7

Guo R, He X (2013) Spatial variations and ecological risk assessment of heavy metals in surface sediments on the upper reaches of Hun River, Northeast China. Environ Earth Sci 70(3):1083-1090

Han L, Song Y, Duan L, Yuan P (2015) Risk assessment methodology for Shenyang chemical industrial park based on fuzzy comprehensive evaluation. Environ Earth Sci. doi:10.1007/s12665-015-4324-8

Huang JY, Liao WP, Lai SM (2013) Removal of 2,4-dichlorophenol and pentachlorophenol from aqueous media by electrochemical process. Environ Earth Sci 68(8):2281-2288

Im J, Gil K (2013) Changes in the characteristics of organic compounds depending on the nitritation efficiency. Environ Earth Sci 70(3):1297-1305

Im J, Jinyoung B, Hyokwan H (2014) Correlation between nitrite accumulation and the concentration of $\mathrm{AOB}$ in a nitritation reactor. Environ Earth Sci 72(1):289-297

Kalbacher T, Delfs JO, Shao H, Wang W, Walther M, Samaniego L, Schneider C, Musolff A, Centler F, Sun F, Hildebrandt A, Liedl R, Borchardt D, Krebs P, Kolditz O (2012) The IWAS-toolbox: software coupling for an integrated water resources management. Environ Earth Sci 65(5):1367-1380. doi:10.1007/s12665011-1270-y

Kalbus E, Kalbacher T, Kolditz O, Krüger E, Seegert J, Teutsch G, Krebs P, Borchardt D (2012) IWAS-integrated water resources management under different hydrological, climatic and socioeconomic conditions. Environ Earth Sci 65(5):1363-1366. doi: 10.1007/s12665-011

Kolditz O, Bauer S, Bilke L, Böttcher N, Delfs JO, Fischer T, Görke UJ, Kalbacher T, Kosakowski G, McDermott CI, Park CH, Radu F, Rink K, Shao H, Shao HB, Sun F, Sun YY, Singh AK, Taron J, Walther M, Wang W, Watanabe N, Wu N, Xie M, Xu W, Zehner B (2012a) OpenGeoSys: an open-source initiative for numerical simulation of thermo-hydro-mechanical/chemical $(\mathrm{THM} / \mathrm{C})$ processes in porous media. Environ Earth Sci 67(2):589-599. doi:10.1007/s12665-012-1546-x

Kolditz O, Rink K, Shao HB, Kalbacher T, Zacharias S, Kunkel R, Dietrich P (2012b) International viewpoint and news: data and modelling platforms in environmental Earth sciences. Environ Earth Sci 66:1279-1284. doi:10.1007/s12665-012-1661-8

Lei $\mathrm{H}, \mathrm{Xu} \mathrm{G}$, Guo J et al (2013) A review on the mechanism and affecting factors of nitrous oxide emission in constructed wetlands. Environ Earth Sci 68(8):2171-2180

Lei K, Zhou G, Guo F, Khu ST, Mao G, Peng J, Liu Q (2015) Simulation-optimization method based on rationality evaluation 
for waste load allocation in Daliao River. Environ Earth Sci. doi:10.1007/s12665-015-4334-6

Li B, Hu X, Liu R, Zeng P, Song Y (2015a) Occurrence and distribution of phthalic acid esters and phenols in Hun River Watersheds. Environ Earth Sci. doi:10.1007/s12665-015-4299-5

Li H, Zhou B, Tian Z, Song Y, Xiang L, Wang S, Sun C (2015b) Efficient biological nitrogen removal by Johannesburg-Sulfur autotrophic denitrification from low COD/TN ratio municipal wastewater at low temperature. Environ Earth Sci. doi:10.1007/ s12665-015-4231-Z

Liu R, Tan R, Li B, Song Y, Zeng P, Li Z (2015a) Overview of POPs and heavy metals in Liao River Basin. Environ Earth Sci. doi:10. 1007/s12665-015-4317-7

Liu X, Hu X, Wang J, Song Y, Wang M, Liu R, Duan L (2015b) Evaluating properties of protein in waste activated sludge for volatile fatty acid production: effect of $\mathrm{pH}$. Environ Earth Sci. doi:10.1007/s12665-015-4194-0

Liu X, Wang J, Duan L, Song Y, Hu X, Wei J (2015c) Enhancing the production of butyric acid from sludge fermentation with an emphasis on zinc, cobalt, cuprum, ferrum and manganese. Environ Earth Sci. doi:10.1007/s12665-015-4289-7

Liu X, Xiang L, Song Y, Qian F, Meng X (2015d) The effects and mechanism of alkalinity on the phosphate recovery from anaerobic digester effluent using dolomite lime. Environ Earth Sci. doi:10.1007/s12665-015-4335-5

Luo Z, Qiu Z, Wei Q et al (2014) Dynamics of ammonia-oxidizing archaea and bacteria in relation to nitrification along simulated dissolved oxygen gradient in sediment-water interface of the Jiulong river estuarine wetland, China. Environ Earth Sci 72(7):2225-2237

Ma Y, Qin Y, Zheng B, Zhang L, Zhao Y (2015) Seasonal variation of enrichment, accumulation and sources of heavy metals in suspended particulate matter and surface sediments in the Daliao River and Daliao River estuary, Northeast China. Environ Earth Sci. doi:10.1007/s12665-015-4325-7

Pascual Aguilar JA, Andreu V, Vazquez P et al (2014) Presence and spatial distribution of emerging contaminants (drugs of abuse) in protected agroecological systems (L'Albufera de Valencia Coastal Wetland, Spain). Environ Earth Sci 71(1):31-37

Peng J, Ren Z, Song Y, Yu H, Tang X, Gao H (2015a) Impact of spring flooding on DOM characterization in a small watershed of the Hun River, China. Environ Earth Sci. doi:10.1007/s12665015-4248-3

Peng J, Song Y, Yuan P, Liu R (2015b) Re-activation and succession of functional microbial communities during long-term storing sludge granulation. Environ Earth Sci. doi:10.1007/s12665-0154296-8

Qian F, He M, Song Y, Tysklind M, Wu J (2015) A bibliometric analysis of global research progress on pharmaceutical wastewater treatment during 1994-2013. Environ Earth Sci. doi:10. 1007/s12665-015-4183-3

Qin W, Song Y, Dai Y, Qiu G, Ren M, Zeng P (2015) Treatment of berberine hydrochloride pharmaceutical wastewater by $\mathrm{O} 3 / \mathrm{UV} /$ $\mathrm{H} 2 \mathrm{O} 2$ advanced oxidation process. Environ Earth Sci. doi:10. 1007/s12665-015-4192-2

Quiers M, Batiot-Guilhe C, Bicalho CC (2014) Characterisation of rapid infiltration flows and vulnerability in a karst aquifer using a decomposed fluorescence signal of dissolved organic matter. Environ Earth Sci 71(2):553-561

Ramakrishnan A, Lee B, Kao J (2015) Emerging contaminants in landfill leachate and their sustainable management. Environ Earth Sci 73(3):1357-1368

Rink K, Kalbacher T, Kolditz O (2012) Visual data management for hydrological analysis. Environ Earth Sci 65(5):1395-1403. doi:10.1007/s12665-011-1230-6
Sauer U, Dietrich P (2014) NovCare 2013 (Novel methods for subsurface characterization and monitoring: from theory to practice). Environ Earth Sci 72(5):1299-1302

Schirmer M, Reinstorf F, Leschik S et al (2011) Mass fluxes of xenobiotics below cities: challenges in urban hydrogeology. Environ Earth Sci 64(3):607-617

Seegert J, Markov D, Kolditz O, Krebs P, Borchardt D (2014a) IWAS II: integrated water resources management under different hydrological, climatic and socio-economic conditions. Environ Earth Sci 72(12):4673-4676

Seegert J, Berendonk TU, Bernhofer C et al (2014b) Integrated water resources management under different hydrological, climatic and socio-economic conditions: results and lessons learned from a transdisciplinary IWRM project IWAS. Environ Earth Sci 72(12):4677-4687

Shan Y, Zeng P, Liu Y, Liu R, Song Y, Du J (2015) Adsorption of berberine by polymeric resin H103: kinetics and thermodynamics. Environ Earth Sci. doi:10.1007/s12665-015-

Song Y, Qian F, Gao Y, Huang X, Wu J, Yu H (2015a) PHREEQC program based simulation of magnesium phosphates crystallization for phosphorus recovery. Environ Earth Sci. doi:10.1007/ s12665-015-4340-8

Song Y, Wei J, Ma Y, Zeng P, Kong M (2015b) Removal and recovery of amantadine from water by liquid-liquid extraction. Environ Earth Sci. doi:10.1007/s12665-015-4302-1

Sun F, Shao H, Wang W, Bilke L, Yang Z, Huang Z, Kolditz O (2012) Groundwater deterioration in Nankou-a suburban area of Beijing: data assessment and remediation scenarios. Environ Earth Sci. doi:10.1007/s12665-012-1600-8

Tang W, Zhang H, Shan B et al (2015) Accumulation and risk assessment of sedimentary trace metals in response to industrialization from the tributaries of Fuyang River system. Environ Earth Sci 73(5):1975-1982

Tian Z, Xin W, Song Y, Li F (2015a) Simultaneous organic carbon and nitrogen removal from refractory petrochemical dry-spun acrylic fiber wastewater by hybrid A/O-MBR process. Environ Earth Sci. doi:10.1007/s12665-015-4210-4

Tian Z, Zhang J, Song Y (2015b) Several key factors influencing nitrogen removal performance of anammox process in a biofilter at ambient temperature. Environ Earth Sci. doi:10.1007/ s12665-015-4232-y

Tu X, Xiao S, Song Y, Zhang D, Zeng P (2015) Treatment of simulated berberine wastewater by electrochemical process with $\mathrm{Pt} / \mathrm{Ti}$ anode. Environ Earth Sci. doi:10.1007/s12665-015-4323-9

Wan D, Xiao S, Cui X, Zhang Q, Song Y (2015) Removal of $\mathrm{Cu}^{2+}$ from aqueous solution using proton exchange membrane by Donnan dialysis process. Environ Earth Sci. doi:10.1007/ s12665-015-4214-0

Wei L, Song Y, Meng X, Pic JS (2015) Combination of Fenton oxidation and sequencing batch membrane bioreactor for treatment of dry-spun acrylic fiber wastewater. Environ Earth Sci. doi:10.1007/s12665-015-4091-6

Xiao S, Song Y, Tian Z, Tu X, Hu X, Ruixia L (2015) Enhanced mineralization of antibiotic berberine by the photoelectrochemical process in presence of chlorides and its optimization by response surface methodology. Environ Earth Sci. doi:10. 1007/s12665-015-4209-x

Xie ML, Bauer S et al (2006) Numerical simulation of reactive processes in an experiment with partially saturated bentonite. J Contam Hydrol 83(1-2):122-147

Yang J, Lei K, Khu S, Meng W, Qiao F (2015) Assessment of water environmental carrying capacity for sustainable development using a coupled system dynamics approach applied to the Tieling of the Liao River Basin, China. Environ Earth Sci. doi:10.1007/ s12665-015-4230-0 
Yu H, Song Y, Gao H, Liu L, Yao L, Peng J (2015) Applying fluorescence spectroscopy and multivariable analysis to characterize structural composition of dissolved organic matter and its correlation with water quality in an urban river. Environ Earth Sci. doi:10.1007/s12665-015-4269-y

Zeng P, Du J, Song Y, Liu Y, Liu R, Zhang P, Xiao S (2015) Efficiency comparison for treatment of amantadine pharmaceutical wastewater by Fenton, ultrasonic and Fenton/ultrasonic processes. Environ Earth Sci. doi:10.1007/s12665-015-4204-2
Zhi E, Song Y, Duan L, Yu H, Peng J (2015a) Spatial distribution and diversity of microbial community in large-scale constructed wetland of the Liao River Conservation Area. Environ Earth Sci. doi:10.1007/s12665-015-4021-7

Zhi E, Yu H, Duan L, Han L, Liu L, Song Y (2015b) Characterization of the composition of water DOM in a surface flow constructed wetland using fluorescence spectroscopy coupled with derivative and PARAFAC. Environ Earth Sci. doi:10.1007/s12665-0154148-6 